\title{
Civic Participation and Engagement in Electronic Social Networks: Trends in Lithuania ${ }^{1}$
}

\author{
Jurgita Jurkevičienė, Eglè Butkevičienė \\ Kauno technologijos universitetas \\ A. Mickevičiaus 37, LT-44244 Kaunas \\ cross $^{\text {ref }}$ http://dx.doi.org/10.5755/j01.ppaa.17.1.20604
}

\begin{abstract}
The debates on how to foster civic participation have intensified in current years, especially with the coming of digital era. New electronic social networks and other digital platforms promising the unseen possibilities for variety of activities including civic participation, has been emphasized as a factor facilitating civic engagement (Smith, 2013). In this article, we test a hypothesis that people, who are actively engaged in electronic social networks at the same time are more likely participate in civic activities. The findings show that electronic social networks generally have a positive relationship with participation in various civic activities. More specifically, we find that engagement in specific networked activities, such as "offering topics for discussion", "contributing to organized events" or "publication of content" have more influence on civic participation than others.
\end{abstract}

Raktažodžiai: elektroniniai socialiniai tinklai, pilietinis dalyvavimas, politinis aktyvumas, kiekybinis tyrimas, visuomenès nuomonès apklausa.

Keywords: electronic social networks, civic participation, political participation, quantitative research, public opinion survey.

\section{Introduction}

In current years, there is a wide academic debate about the factors fostering civic participation. One cluster of factors is primarily stemming from the idea that

\footnotetext{
1 Article has been developed under the project "International Social Survey Programme: Social Networks, Social Welfare and Religion, ISSP LT-STR", implemented by Vytautas Magnus University and Kaunas University of Technology and funded by Research Council of Lithuania (agreement No. S-MIP-17-120). The goal of this project is to conduct comparative research on behavioral patterns and public attitudes towards social networks, religious practices and perception of social welfare and to continue the implementation of the International Social Survey Programme (ISSP) in Lithuania.
} 
engagement in other activities, including active participation in electronic social networks (or e-social networks) such as Facebook, Google+, Twitter, may also facilitate civic participation. The analysis here is focussed on "how digital communication technologies extend the context of civic life and change the motivations for civil commitment" (Bala, 2014, p. 767).

Thus, the main aim of this article is to analyse the relation between engagement into e-social networks and civic participation, employing data from public opinion survey. Our hypothesis lies in an assumption that people, who are actively engaged in e-social networks at the same time are more likely participate in civic activities. Such a hypothesis has been based on A. Smith's (2013) findings and tested within the Lithuanian population. We have used data of public opinion survey that had been conducted in 2013. For the explanation of our findings we have also used additional data sets such as statistics of the Central Electoral Commission of the Republic of Lithuania on the population's participation in parliamentary elections, and the statistics of Civil Society Institute on the population's participation in civic activities (2016).

The findings of this article allow us to reflect on current trends of engagement in e-social networks and civic participation among Lithuanian population. This article has been developed under the project "International Social Survey Programme: Social Networks, Social Welfare and Religion, ISSP LT-STR", funded by Research Council of Lithuania (agreement No. S-MIP-17-120).

\section{Theoretical background and hypothesis}

There is much of the research conducted on the motivation, forms and ways of civic participation, starting from seminal works of G. A. Almond and S. Verba (1963), S. R. Arnstein (1969), R. D. Putnam (2000) and other authors. Debates include the forms that range from expressing beliefs about some political or public issue to participating in voting or joining political parties (Campbell et al., 2012). The current social media environment presents a variety of choices for reinforcing new types, ways and/or new spaces of participation. Thus, with the spread of information communication technologies (ICT), the research agenda on civic participation has also changed, including the impact of ICT on civic activities.

The research on relationship between civic participation and engagement in esocial networks and online communication is not a completely new topic and the existing findings could be classified into several topics. One stream of research is focussed on e-social networks as new spaces for civic participation. This means that new media does not add some new forms, but offers the new spaces to employ traditional forms. E. g. instead of signing petition offline, people sign online petitions; instead of contacting a government official via offline methods, people use online platforms. As emphasized by A. Smith (2013) participants of electronic social networks understand social networking sites as spaces that "are not a separate realm of political activity". It is just another mean to express their civic position. However, the choice of media is rather complex process based on selectivity, as argued by $\mathrm{L}$. 
Feldman, M. Wojcieszak, N. J. Stroud, B. Bimber (2018).

Another major topic in research is related to analysis of the impact that e-social networks have on civic participation. Online social media has proven itself to be a powerful tool of political and civic mobilization in Arab Spring (Wolfsfeld, Segev, Sheafer, 2013) or in other social movements such as ' $15 \mathrm{M}$ movement' in Spain (Perugorría, Tejerina, 2013). The impact of ICT spread and online communication on civic participation has been emphasized by many authors, including A. Smith (2013), P. Yang, M. Ogawa (2018), B. Gleason, S. Von Gillern (2018), X. Zhang, W.-Y. Lin (2018), R. P. Yu (2016) and other scholars. P. Yang, M. Ogawa (2018) analysed how civic engagement of young people in China and Japan has been influenced by their use of social media. They also focussed on political activism as one of the major components of civic engagement. B. Gleason, S. Von Gillern (2018) explored how the social media use supports the development of digital citizenship in the population of secondary school students. X. Zhang, W.-Y. Lin (2018) examined the relationship between social media use and political participation focusing on mainland China, Hong Kong, and Taiwan and found that "capitalenhancing social media use facilitated political engagement, whereas recreational use might dampen engagement" (p. 217). The study also revealed "the political potential of online entertainment content in creating an informed citizenship within a censored online environment" (Zhang, Lin, 2018, p. 225).

R. P. Yu (2016), who paid a special attention to the relationship between passive and active non-political social media use and political expression on Facebook and Twitter, found that active use of non-political social media (such as Facebook and Twitter) is positively related to political expression, and this relationship might be explained by political efficacy. The authors conclude "suggesting that people's private use of social media may cultivate public civic attitudes and contribute to political engagement" (Yu, 2016, p. 419).

The PEW Research Centre's study "Civic Engagement in the Digital Age" shows that the participation in civic life online is more common to the same groups who "have always been more likely to be active in politics and community affairs offline" (Smith, 2013). This empirical study explicitly reveals that people active online, are frequently active also in other aspects of civic life. Thus, our hypothesis builds on previous work of the PEW Research Centre (Smith, 2013) assuming that H1: that people, who are actively engaged in e-social networks at the same time are more likely to participate in offline civic activities:

H1A: people who are more actively engaged in e-social networks, are also more likely to participate in national elections;

- HIB: people who are more actively engaged in e-social networks, are also more active in different civic activities;

- HIC: people who are more actively participating in specific networked activities, are more likely to participate in national elections; 
- HID: people who are more actively participating in specific networked activities, are more active in different civic activities.

The reason why it is interesting to test this hypothesis lies in the specifics of the case. We test this hypothesis within Lithuanian population, that exhibits comparatively high level of engagement in e-social networks but at the same time comparatively low level of civic participation (as explained further in the data analysis part).

\section{Methods and data}

In order to analyse the relationship between civic participation and citizen engagement in e-social networks, we employ quantitative research strategy and method of secondary data analysis. The article uses three data sources, i.e. the statistics of the Central Electoral Commission of the Republic of Lithuania (2016) on the population's participation in parliamentary elections, the statistics of Civil Society Institute (2016) on the population's participation in civic activities, and a survey on virtual social networks in Lithuania (Butkevičienè et al., 2013). Using the first and the second data sets, the study presents the general trends of civic participation in Lithuania; whereas the third and the main data set has been used in the article for investigation of the connection between the civic participation and citizens' e-social networking. All these data sources are open-access and stored (1) on the website of the Central Electoral Commission of the Republic of Lithuania, (2) on the website of the Civil Society Institute, and (3) in Lithuanian Data Archive for Humanities and Social Sciences (LiDA), respectively.

The main source of data in this article is the survey on virtual social networks (Butkevičienė et al., 2013), conducted in January-February, 2013. It was a representative survey of the Lithuanian population, with a sample formed on the basis of the Address Register of the Republic of Lithuania managed by the State Enterprise Centre of Registers. The sample was formed by applying a multi-level stratified sampling of addresses. Specifically, the study included the Lithuanian population of 18 years and older, a total of 1187 individuals, of which $58.5 \%$ were women and $41.5 \%$ were men. The average age of the sample is 49 years. More than a half (54.9\%) of respondents use the Internet, most of them - on a regular basis $(52.1 \%)$, i.e. at least once a week (see Table 1).

Dependent variable. Based on the assumptions discussed in the theoretical part, the civic participation of the population as a dependent variable is distinguished. The dependent variable is operationalised using the questions presented in the survey on virtual social networks. First, it refers to the question "Currently, some people do not vote for different reasons. Did you vote in the last parliamentary elections in October 2012?". The respondents, who participated in the survey, could choose from three options of the answers: $0=I$ did not have a voting right in the last elections, $1=$ Yes, I voted, $2=$ No, I did not vote. Since the survey had no respondents without a voting right, these answers were excluded from the further analysis. The second question 
operationalising the dependent variable is as follows: "Have you performed any of the following actions over the past year? 1) Contacted a politician, 2) Contacted state controlling institutions, 3) Participated in the activities of a political party, 4) Participated in the activities of public organizations, movements, 5) Volunteered in a public or civic campaign, 6) Signed a petition (not online), 7) Participated in a demonstration, rally or a protest, 8) Participated in strike action, 9) Boycotted products of any firm or country, 10) Donated money, things to charity, or otherwise supported people or public organizations, 11) Met with journalists or wrote or spoke in person in the media, 12) Contacted a lawyer, court or public prosecutor's office for the matters of defence of a collective interest, 13) Sent by email political information of political or civic nature, proclamations, or signed up a petition, 14) Participated in environment cleaning campaigns, 15) Participated in local community activities". Respondents again could choose from three options of the answer: $1=$ Yes, $2=$ No, 8 $=$ I do not know (the answers "I do not know" were excluded from the further analysis).

Table 1. Socio-demographic characteristics of a survey sample, $\mathbf{N}=1187$

\begin{tabular}{|c|c|c|c|}
\hline & Characteristics & $\mathbf{N}$ & Percentage \\
\hline Age & 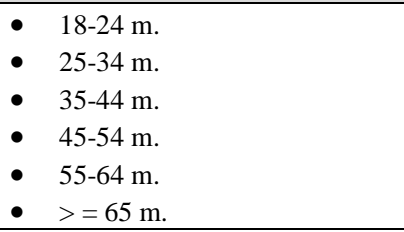 & $\begin{array}{l}130 \\
169 \\
184 \\
226 \\
202 \\
276\end{array}$ & $\begin{array}{l}11,0 \% \\
14,2 \% \\
15,5 \% \\
19,0 \% \\
17,0 \% \\
23,3 \%\end{array}$ \\
\hline Gender & $\begin{array}{ll}\text { - } & \text { Female } \\
\text { - } & \text { Male } \\
\end{array}$ & $\begin{array}{l}694 \\
493 \\
\end{array}$ & $\begin{array}{l}58,5 \% \\
41,5 \% \\
\end{array}$ \\
\hline Internet usage & $\begin{array}{ll}- & \text { Yes } \\
\text { - } & \text { No } \\
\end{array}$ & $\begin{array}{l}652 \\
536\end{array}$ & $\begin{array}{l}54,9 \% \\
45,1 \%\end{array}$ \\
\hline $\begin{array}{l}\text { Frequency of the } \\
\text { Internet usage }\end{array}$ & $\begin{array}{ll}\text { - } & \text { Every day } \\
\text { - } & \text { At least several times a week } \\
\text { - } & \text { At least once a week } \\
\text { - } & \text { At least once a month } \\
\text { - } & \text { Several times a year } \\
\text { - } & \text { Less than several times a year }\end{array}$ & $\begin{array}{c}333 \\
180 \\
105 \\
29 \\
3 \\
2\end{array}$ & $\begin{array}{l}51,1 \% \\
27,6 \% \\
16,1 \% \\
4,4 \% \\
0,5 \% \\
0,3 \%\end{array}$ \\
\hline
\end{tabular}

Source: Empirical data on virtual social networks in Lithuania (Butkevičienė et al., 2013).

Independent variables. Independent variables have been also operationalised using the questions from the survey on virtual social networks. The first independent variable (i.e. Level (frequency) of engagement in e-social networks) has been used to test a hypothesis on the relationship between civic participation and engagement in esocial networks such as Facebook or Google+ (H1A, H1C). The independent variable is defined by the following question: "People use the internet for a variety of purposes. Below we will describe some ways to use the Internet. Please tell how often do you use each of them". In this article, we use data on just one item, in which 
respondents were asked to answer how often they use e-social networking portals. The respondents chose their answers from a 7 -point Likert scale, where $1=$ every day, $2=$ at least several times a week, $3=$ at least once a week, $4=$ at least once a month, $5=$ several times a year, $6=$ less than several times a year, $7=$ never.

The second independent variable (i.e. Activities in e-social networks) has been used to check a hypothesis on the relationship between civic participation and engagement into various networking activities (H1B, H1D). This variable has been defined by the question: "Over the e-social network that you visit most often, how often you: 1) publicise the material (e.g., photos, videos), 2) Organize events, 3) Offer topics for conversations, 4) Contribute to the events organized, 5) Participate in the proposed conversations, 6) Participate in theme forums, 7) Comment on friends' photos and/or posts, 8) Send friends invitations to people you know, 9) Send friends invitations to strangers, 10) Edit my profile, 11) Read information, 12) Engage in commercial activities, 13) Play games, 14) Evaluate (e.g. "Like", 15) Share information". In each of the fifteen statements, the respondents were choosing their answers on the aforementioned 7-point Likert scale $(1=$ every day, $7=$ never $)$.

Binary logistic regression. The regression method has been chosen to test all four hypotheses (H1A, H1B, H1C, H1D). Since dependent variable does not exhibit normal distribution and the scales of both dependent and independent variables are nominal or range-type, specifically, the binary logistic regression method has been used to test hypothesis. As control variables, we have been using age, gender, education and place of residence of the population. The suitability of the regression models for data was validated in several ways. First, by applying the coefficient of determination $\mathrm{R}^{2}$ (Nagelkerke). If this coefficient has a value more than 0.2 , then the model is considered to be appropriate for the data. Secondly, using the Cook's measure, calculated individually for each member of the sample. If the mean of the measure is beyond the mark of 1.0, it is considered that there are not much significant exclusions in the sample and the model is usable for the data. Thirdly, using $\mathrm{Chi}^{2}$ test. If $p$ value of this test is lower than 0.05 , it is considered that the model fits the data.

Limitations. Several aspects determine the limitations of this research study. First, the relatively old data that we use to test hypothesis, as the survey has been conducted in January-February, 2013. Second, an extremely small number of persons participating in particular civic activities. Small numbers of respondents in particular complicate the statistical analysis and, in certain cases, some relationships may not be fully recognized.

\section{Data analysis and discussion}

The survey shows that Lithuanians are relatively passive in both elections and civic activities. For example, according to the data of the Central Election Commission (2016), only half (50.64\%) of the citizens with the right to vote took part in the last elections of the Parliament of the Republic of Lithuania that are being held in October 2016. Lithuanian electoral activity is almost 15\% points below the world's average. Lithuania is behind all the Scandinavian (e.g. Denmark, Finland, Sweden, 
Norway) and many Western European countries (e.g. Germany) (IDEA, 2018).

Regression analysis was used to find out how participation in national elections is related to the general activity in e-social networks (H1A) as well as in the specific networked activities (H1C). The results show that general activity on websites such as Facebook or Google+ does not have a statistically significant impact on participation in national elections (see Table 2). Thus, Lithuanian residents who use e-social networks every day, or once a month, or do not use them at all, are equally passive in national elections. Regression analysis also shows that specific networked activities, nevertheless, affect participation in the elections. Therefore, users who often offer topics for discussions in e-social networks are almost twice as active in the national elections. Meanwhile persons, who participate in the offered discussions on e-social networks, organize virtual events, and read the information in the elections are slightly less active than others. Analysed networked activities also included publication of material, contributing to organized events, participation in theme forums, commenting on friends' photos and/ or posts, sending email invitations to friends and unknown persons, editing personal profile, engaging in commercial activities, playing games, evaluating materials and sharing information, but the level of engagement in these activities do not affect participation in elections.

Table 2. Relationship between participation in national elections and level of engagement in e-social networks, $\mathrm{N}=320$

\begin{tabular}{|c|c|c|}
\hline & B & $\operatorname{Exp}(\mathbf{B})$ \\
\hline Activity in electronic social networks & .077 & 1.080 \\
\hline $\begin{array}{l}\text { Participation in network activities: } \\
\text { - } \quad \text { Publication of content (e.g., photos, videos) } \\
\text { - } \quad \text { Organisation of events } \\
\text { - } \quad \text { Contributing to the events organized } \\
\text { - } \quad \text { Participation in the proposed discussions } \\
\text { - } \quad \text { Commenting on friends' photos or posts } \\
\text { - } \quad \text { Sending invitations for joining as friends to familiar persons for joining as friends to unfamiliar persons } \\
\text { - } \quad \text { Editing personal profile } \\
\text { - } \quad \text { Engagementing in commercial activities } \\
\text { - } \quad \text { Playing games } \\
\text { - } \quad \text { Sharing information (e.g. "Like") } \\
\end{array}$ & $\begin{array}{c}-.005 \\
-.456^{*} \\
.506^{*} \\
.136 \\
-.233^{*} \\
.034 \\
.014 \\
-.021 \\
-.096 \\
.058 \\
-.262^{*} \\
.173 \\
-.111 \\
.160 \\
-.124\end{array}$ & $\begin{array}{c}.995 \\
.634^{*} \\
1.659^{*} \\
1.146 \\
.792^{*} \\
1.034 \\
1.014 \\
.979 \\
.908 \\
1.060 \\
.770^{*} \\
1.189 \\
.895 \\
1.173 \\
.883\end{array}$ \\
\hline $\begin{array}{l}\text { Control variables: } \\
-\quad \text { Age } \\
-\quad \text { Gender } \\
-\quad \text { Education } \\
-\quad \text { Place of residence } \\
\end{array}$ & $\begin{array}{l}-.555^{*} \\
.512 \\
-.350^{*} \\
.380^{*}\end{array}$ & $\begin{array}{l}.574 * \\
1.669 \\
.705^{*} \\
1.462 *\end{array}$ \\
\hline $\begin{array}{l}\mathrm{R}^{2}(\text { Nagelkerke R Square })=.314 \\
\text { Chi } 2=.000 \\
\text { Cook }(\text { mean })=.071\end{array}$ & & \\
\hline
\end{tabular}

Source: Empirical data on virtual social networks in Lithuania (Butkevičienė et al., 2013). 
Based on these findings, the hypothesis $\mathrm{H} 1 \mathrm{~A}$, stating that individuals who are more actively engaged in e-social networks, are more likely to participate in national elections, is rejected. On the other hand, the hypothesis $\mathrm{H} 1 \mathrm{C}$, according to which individuals that are more actively participating in specific networked activities, are more likely to participate in national elections, was partially confirmed. Such findings coalesce with the studies of other authors, showing that the use of e-social networks has the potential of developing into a civic participation (offline, as well as online). A mandatory condition here is users' involvement in specific activities that encourage such participation (Abdu et al., 2016; Bode, 2012; Espinosa et al. 2017). One of such activities could be willingness to suggest discussions on various civic and political issues, as well as active participation in these discussions. Following the assumptions of L. Zaheer (2016), the more time users spend being politically active in the e-social networks, the more active they will be performing more traditional civic actions, for example, participating in the national elections.

Another significant example of the expression of citizenship is participation in various civic activities. According to the data of the Civil Society Institute (2016), minority of Lithuanian residents has taken part in every of the eighteen analysed civic activities. The most popular forms of civic activities among the residents are those that require less personal attempts and initiatives, especially giving to charity and different support for people or public organisations (44\%), participation in environment cleaning activities (41\%), and also, in local community activities (29\%). Although in many cases the participation in these "popular" activities is momentary, it is undoubtedly significant for creating a more solid society, i.e. for developing the sense of solidarity, for encouraging support and attention to the others, especially to those, who are socially vulnerable, for fighting with mistrust, etc. Nevertheless, neither of "popular" activities are oriented towards affecting political decisions and making the influence on the state through the political system.

The civic activities related to politics and requiring more personal attempts, are still less popular in Lithuania. According to the data of the Civil Society Institute (2016), only less than $10 \%$ of the residents of the country took part in such activities in 2015. Specifically, approximately just every ninth person signed a petition offline $(11 \%)$, every eleventh boycotted certain products $(9 \%)$ for ethical (moral or political reasons), and just $7 \%$ of respondents indicated that he/she was participating in the activities of public organization or movement, sending or announcing over the internet any political information, virtually signing a petition, or participating in an online political debate. Only a few individuals claimed to have addressed a politician, participated in trade unions, took part free of charge in a public or civic campaign, party or other public organization, demonstration, rally or a picket, in a strike action, as well as contacted a lawyer, a court or a prosecutor's office in the matters of defending public interest (see Table 3). The data indicate that $34 \%$ of population took part in none of civil activities in 2015. According to the estimations of the Civil Society Institute (2016), the average of civilian power of Lithuania amounts to merely 32 points out of 100 possible. Thus, these indicators, again, fall substantially below 
the numbers of many other European countries (e.g. Norway, Sweden, Denmark, Hungary, etc.) (ICCS, 2009; Kuzmickaitè, 2017).

Table 3. Citizens' participation in civic activities, $N=1012$

\begin{tabular}{|l|c|}
\hline & Percentage \\
\hline Donated money, things, or otherwise supported people or public organizations for charity & 43.5 \\
\hline Participated in environment cleaning campaigns & 41.1 \\
\hline Participated in activities of local communities & 28.5 \\
\hline Addressed the national controlling institutions, informing about the infringements of laws & 12.3 \\
\hline Signed a petition (not on the internet) & 11 \\
\hline Boycotted the products of any company or country because of ethical (moral) or political motives & 9.1 \\
\hline Bought the products of any company or country because of ethical (moral) or political motives & 8.4 \\
\hline Participated in the activity of public organisations or movements & 7.3 \\
\hline $\begin{array}{l}\text { Over the internet sent, announced the information of civic or political nature, signed a petition, }, \\
\text { participated in a political discussion or group }\end{array}$ & 6.9 \\
\hline Addressed the politicians & 6.4 \\
\hline Participated in trade union's activity & 5.8 \\
\hline Participated in social activity performed by a religious community & 5.5 \\
\hline Free of charge participated in a public or civic campaign & 5 \\
\hline Participated in the activity of a party or political organisation & 4.9 \\
\hline Met the journalists or yourself wrote, spoke in the press, television, radio & 4.8 \\
\hline Participated in a demonstration, rally or picket & 3.1 \\
\hline $\begin{array}{l}\text { Addressed the lawyer, court or prosecuting office on the matters of public, collective interest } \\
\text { defence }\end{array}$ & 2.7 \\
\hline Participated in a strike action & 1.2 \\
\hline
\end{tabular}

Source: Civil Society Institute (2016).

Again, the regression analysis was used to investigate how participation in different civic activities is related to the general activity in e-social networks (H1B) as well as the specific networked activities (H1D). For this analysis, we have used the three most popular civic activities in Lithuania, i.e. donation to the charity, participation in the environment cleaning campaigns and participation in local community activities. Regression analysis shows that users, who participate more often in e-social networks are significantly more likely to make donation or support people and political organizations (see Table 4). The latter tendency can be explained by the fact that in social networks individuals receive a lot of timely information about the need for support, their potential recipients, and opportunities to donate both offline and online. Moreover, according to D. G. Saxton and L. Wang (2014), the decisions to donate and to contribute in e-social networks are usually impulsive, stimulated by strong emotions and social pressure from family and friends.

Finally, regression analyses on the data-set representing remaining civic activities reveals that more active users in e-social networks are almost four times more likely to participate in public or civic campaigns, and also, they are more likely to address the politicians. The users who often publish material on e-social networks and contribute to events organized by others are more likely to participate in public or civic campaigns or to be active in public organizations and movements. Meanwhile, those who play games, organize events or comment on their friends' photos and 
recordings on e-social networks, are relatively less involved in civic activities than other users (see Table 5).

Table 4. Relationship between most popular civic participation forms and level of engagement in e-social networks, $\mathrm{N}=325$

\begin{tabular}{|c|c|c|c|}
\hline & $\begin{array}{l}\text { Donation to } \\
\text { charity }\end{array}$ & $\begin{array}{l}\text { Participation in } \\
\text { environment } \\
\text { cleaning } \\
\text { campaigns }\end{array}$ & $\begin{array}{l}\text { Participation } \\
\text { in local } \\
\text { community } \\
\text { activities }\end{array}$ \\
\hline & B $(\operatorname{Exp}(B)$ & B $(\operatorname{Exp}(B)$ & B $(\operatorname{Exp}(B)$ \\
\hline Activity in electronic social networks & $.334(1.397)^{*}$ & $.007(1.007)$ & $.054(1.055)$ \\
\hline $\begin{array}{l}\text { Participation in network activities: } \\
\text { - } \quad \text { Publication of content } \\
\text { - } \quad \text { Organisation of events } \\
\text { - } \quad \text { Offering topics for discussions } \\
\text { - } \quad \text { Contributing to organized events } \\
\text { - } \quad \text { Participation in proposed discussions } \\
\text { - } \quad \text { Participation in thematic forums } \\
\text { - } \quad \text { Commenting on friends' photos/ posts } \\
\text { - } \quad \text { Sending invitations for joining as friends to } \\
\text { - } \quad \text { Samiliar persons } \\
\text { - } \quad \text { Editing invitations for joining as friends to } \\
\text { - } \quad \text { Reading information } \\
\text { - Engagement in commercial activities } \\
\text { - Playing games } \\
\text { - } \quad \text { Shaluation (e.g. "Like") } \\
\text { - Sharing information (e.g. "Share") } \\
\end{array}$ & $\begin{array}{l}-0.126(.882) \\
-.068(.934) \\
.264(1.302) \\
.137(1.146) \\
-.079(.924) \\
.104(1.110) \\
-.104(.901) \\
-.029(.972) \\
-.137(.872) \\
.110(1.117) \\
.149(1.161) \\
.089(1.093) \\
-.033(.967) \\
-.110(.896) \\
-.070(.933) \\
\end{array}$ & $\begin{array}{l}-.029(.971) \\
-.010(.990) \\
.073(1.076) \\
.164(1.178) \\
-.012(.988) \\
.116(1.122) \\
-.030(.970) \\
.047(1.049) \\
.021(1.021) \\
-.018(.982) \\
.147(1.158) \\
-.245(.782)^{*} \\
-.018(.983) \\
-.011(.989) \\
-.084(.920) \\
\end{array}$ & $\begin{array}{l}-.140(.870) \\
-.127(.881) \\
.127(1.136) \\
.200(1.222) \\
-.050(.951) \\
-.201(.818) \\
.140(1.150) \\
.072(1.075) \\
.047(1.048) \\
.071(1.073) \\
.181(1.198) \\
.006(1.006) \\
-.088(.916) \\
-.147(.864) \\
.038(1.038) \\
\end{array}$ \\
\hline $\begin{array}{ll}\text { Control variables: } \\
- & \text { Age } \\
\text { - } & \text { Gender } \\
\text { - } & \text { Education } \\
\text { - } & \text { Place of residence } \\
\end{array}$ & $\begin{array}{l}-.097(.908) \\
-.473(.623) \\
-.527(.590)^{*} \\
.199(1.220) \\
\end{array}$ & $\begin{array}{l}-.092(.912) \\
-.180(.835) \\
.029(1.029) \\
.422(1.525)^{*} \\
\end{array}$ & $\begin{array}{l}-.189(.828) \\
-.004(1.077) \\
.074(.996) \\
.439(1.551)^{*}\end{array}$ \\
\hline $\begin{array}{l}\text { R2 (Nagelkerke R Square) } \\
\text { Chi2 } \\
\text { Cook (mean) }\end{array}$ & $\begin{array}{l}.217 \\
.000 \\
.035 \\
\end{array}$ & $\begin{array}{l}.091 \\
.326 \\
.068 \\
\end{array}$ & $\begin{array}{l}.132 \\
.113 \\
.069 \\
\end{array}$ \\
\hline
\end{tabular}

Source: Empirical data on virtual social networks in Lithuania (Butkevičienė et al., 2013).

Based on these findings, the hypothesis, claiming that people who are more actively engaged in e-social networks, are also more active in different civic activities is partially confirmed (H1B). At the same time the hypothesis, that people who are more actively participating in specific networked activities, are more active in different civic activities is partially confirmed as well (H1D). These findings, coincide with results of other studies (Ohlin et al., 2010; Valenzuela et al., 2012; Zhang, Lin, 2014) and could be explained by few facts. Firstly, e-social networks are a medium in which individuals reach the new information about different civic initiatives and opportunities for engagement. Secondly, e-social networks are increasingly becoming a place, where different civic initiatives are actually being implemented. For this reason, active users have more opportunities to take part in an online public or civic 
campaigns, or even to address politicians.

Table 5. Relationship between other civic participation forms and level of engagement in e-social networks, $\mathrm{N}=320$

\begin{tabular}{|c|c|c|c|c|}
\hline & $\begin{array}{c}\text { Addressed } \\
\text { politics }\end{array}$ & $\begin{array}{l}\text { Addressed } \\
\text { controlling } \\
\text { institutions }\end{array}$ & $\begin{array}{l}\text { Participated } \\
\text { in NGOs or } \\
\text { movements }\end{array}$ & $\begin{array}{l}\text { Participated } \\
\text { in public or } \\
\text { civic } \\
\text { campaign }\end{array}$ \\
\hline & B $(\operatorname{Exp}(B)$ & B $(\operatorname{Exp}(B)$ & B $(\operatorname{Exp}(B)$ & B $(\operatorname{Exp}(B)$ \\
\hline Activity in electronic social networks & $.778(2.176)^{*}$ & $.120(1.127)$ & $.023(1.023)$ & $1.311(3.711)^{*}$ \\
\hline $\begin{array}{l}\text { Participation in network activities: } \\
\text { - } \quad \text { Publication of content } \\
\text { - } \quad \text { Organisation of events } \\
\text { - } \quad \text { Offering topics for discussions } \\
\text { - } \quad \text { Participation in proposed discussions } \\
\text { - } \quad \text { Participation in thematic forums } \\
\text { - } \quad \text { Commenting on friends' photos/ posts } \\
\text { - } \quad \text { Sending invitations for joining as } \\
\text { - } \quad \text { friends to familiar persons } \\
\text { - } \quad \text { friends to unfamiliar persons } \\
\text { - } \quad \text { Reading information } \\
\text { - } \quad \text { Engagement in commercial activities } \\
\text { - } \quad \text { Playing games } \\
\text { - } \quad \text { Svaluation (e.g. "Like") } \\
\text { Sharing information (e.g. "Share") }\end{array}$ & $\begin{array}{l}.123(1.131) \\
-.138(.872) \\
.101(1.106) \\
.028(1.028) \\
-.131(.877) \\
.033(1.034) \\
.205(1.227) \\
-.309(.734) \\
.293(1.340) \\
.349(1.417) \\
-.027(.973) \\
.081(1.084) \\
-.332(.718)^{*} \\
-.507(.602) \\
.307(1.360)\end{array}$ & $\begin{array}{l}.168(1.183) \\
-.125(.883) \\
.214(1.238) \\
-.067(.935) \\
-.228(.796) \\
-.049(.952) \\
-.365(.694)^{*} \\
.130(1.138) \\
.157(1.170) \\
.302(1.353) \\
.227(1.255) \\
-.001(.999) \\
-.179(.836) \\
.335(1.398) \\
-.086(.918)\end{array}$ & $\begin{array}{l}.590(1.804)^{*} \\
-.201(.818) \\
.102(1.108) \\
.705(2.023)^{*} \\
-.301(.740) \\
.169(1.185) \\
-.319(.727) \\
.513(1.670) \\
.000(1.000) \\
-.342(.710) \\
.566(1.761) \\
-.114(.893) \\
-.350(.704)^{*} \\
-.317(.728) \\
.352(1.423)\end{array}$ & $\begin{array}{l}.704(2.021)^{*} \\
-.816(.442)^{*} \\
.175(1.191) \\
.987(2.682)^{*} \\
.033(1.034) \\
.187(1.206) \\
-.762(.467) \\
.140(1.150) \\
.450(1.568) \\
-.518(.596) \\
-.174(.840) \\
-.014(.986) \\
-.204(.816) \\
.232(1.262) \\
-.344(.709)\end{array}$ \\
\hline 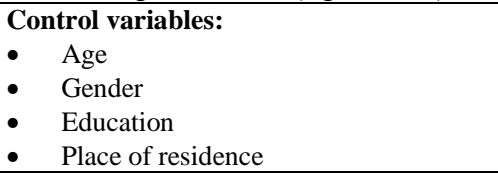 & $\begin{array}{l}-.452(.636)^{*} \\
-.526(1.908) \\
.646(.591) \\
.198(1.219)\end{array}$ & $\begin{array}{l}-.465(.628)^{*} \\
.623(1.865) \\
-.458(.632)^{*} \\
-.223(.800)\end{array}$ & $\begin{array}{l}-.156(.856) \\
-.617(.540) \\
-.013(.988) \\
-.150(.861)\end{array}$ & $\begin{array}{l}-.511(.600) \\
-.143(.867) \\
-.095(.910) \\
-1.892(.151)\end{array}$ \\
\hline $\begin{array}{l}\text { R2 (Nagelkerke R Square) } \\
\text { Chi2 (p value) } \\
\text { Cook (mean) }\end{array}$ & $\begin{array}{l}.273 \\
.013 \\
.069\end{array}$ & $\begin{array}{l}.234 \\
.003 \\
.067\end{array}$ & $\begin{array}{l}.304 \\
.010 \\
.088\end{array}$ & $\begin{array}{l}.378 \\
.019 \\
.074\end{array}$ \\
\hline
\end{tabular}

Source: Empirical data on virtual social networks in Lithuania (Butkevičienė et al., 2013).

\section{Conclusions}

1. The study reflected that civic society is still rather weak in Lithuania. The residents are rather passively participating in civic life, including national elections. In addition, even active citizens often choose the moderate, momentary civic actions, such as charity campaigns, environment cleaning or local community activities. Meanwhile, the initiatives, that require more personal attempts, are unpopular.

2. The findings suggest a positive relationship between engagement in e-social networks and civic participation. However, in case of voting in national elections, the general engagement on websites such as Facebook or Google+ does not have a statistically significant impact on voting behaviour. The study shows that for a statistically significant impact it is important to participate in specific networked 
activities that encourage such participation. One of such activities could be willingness to suggest discussions on various civic and political issues, as well as active participation in these discussions. Following the assumptions of L. Zaheer (2016), the more time users spend being politically active in the e-social networks, the more active they will be performing more traditional civic actions, for example, participating in the national elections.

3. Our analysis revealed that people, who are more engaged in e-social networks are significantly more likely to make donation or support people and political organizations. The analysis also shows that more active users are more likely to participate in public or civic campaigns, and to address the politicians. Talking about specific networked activities, users who are more often publishing material and contributing to events organized by others, are also more likely to participate in public or civic campaigns or public organizations and movements. These findings could be explained by few facts. Firstly, e-social networks are a medium in which individuals reach the new information about different civic initiatives and opportunities for engagement. Therefore, it is not surprising that more active users have more opportunities to participate. Secondly, e-social networks are increasingly becoming a place, where different civic initiatives are actually being implemented, for this reason more active users have more opportunities to take part in them.

\section{References}

1. Abdu, S. D., Mohamad, B., Muda, S. New Perspectives to Political Participation among Youth: The Impact of Facebook Usage. In: B. Mohamad (ed.). European Proceedings of Social \& Behavioural Sciences. Kedah: Future Academy, 2016, p. 127-134.

2. Almond, G. A., Verba, S. The Civic Culture: Political Attitudes and Democracy in Five Nations. London: Sage, 1963.

3. Arnstein, S. R. A Ladder of Citizen Participation. Journal of the American Planning Association, 1969, Vol. 35, p. 216-224.

4. Bala, M. Civic Engagement in the Age of Online Social Networks. Contemporary Readings in Law and Social Justice, 2014, Vol. 6, No. 1, p. 767 - 774.

5. Bode, L. Facebooking It to the Polls: A Study in Online Social Networking and Political Behavior. Journal of Information Technology \& Politics, 2012, Vol. 9, p. 352-369.

6. Butkevičienè, E., Balžekienè, A. Morkevičius, V., Ražanauskaite, J., Šarkute, L., Telešienė, A., Žvaliauskas, G. Virtual Social Networks III, January - February 2013, edition 2: LiDA, 2013. www.lidata.eu/data/quant/LiDA SLT 0268 [2017-11-10].

7. Campbell, D. E., Levinson, M. H., Frederick, M. Making Civics Count: Citizenship Education for a New Generation. Cambridge, MA: Harvard Education Press, 2012.

8. Central Election Commission. Seimo rinkimai: kas, kaip balsavo ir ka išsirinko? 2016 http://www.vrk.lt/naujienos/-/content/10180/1/seimo-rinkimai-kaip-kas-balsavo [201712-05].

9. Civil Society Institute. Civic Empowerment Index, 2016 http://www.civitas.lt/wpcontent/uploads/2016/11/PGI 2015m-tyrimo-ataskaita.pdf [2017-12-11]. 
10. Espinosa, M. Z., Valenzuela, C. R., Cedeño, C. C. Truth or fiction? The Political Use of Social Networks in Offline Political Participation in Ecuadorian Presidential Elections. $\begin{array}{llllll}\text { Análisis } & \text { Político, } & 2017, & \text { Vol. } & 30, & \text { No. }\end{array}$ http://www.scielo.org.co/scielo.php?script=sci_arttext\&pid=S0121-47052017000300130 [2017-12-10].

11. Feldman, L., Wojcieszak, M., Stroud, N. J., Bimber, B. Explaining Media Choice: The Role of Issue-Specific Engagement in Predicting Interest-Based and Partisan Selectivity. Journal of Broadcasting \& Electronic Media, 2018, Vol. 62, No. 1, p. 109-130.

12. Gleason, B., Von Gillern, S. (2018). Digital Citizenship with Social Media: Participatory Practices of Teaching and Learning in Secondary Education. Journal of Educational Technology \& Society, 2018, Vol. 21, No. 1, p. 200-212. http://www.jstor.org/stable/26273880 [2017-11-10].

13. Yang, P., Ogawa, M. Becoming Citizens in the Age of Online Social Networks: Youth's Civic Engagement in China and Japan. In: N. Bilge, M. I. Marino (eds.). Reconceptualizing New Media and Intercultural Communication in a Networked society. IGI Global, 2018, p. 280-302.

14. ICCS. International Civic and Citizenship Education Study, 2009. http://www.nec.lt/failai/1811_Pilietinio_ugdymo_ir_pilietiskumo_tyrimas_ICCS_2009_ Rezultatai_NEC.pdf [2017-11-10].

15. IDEA (International Institute for Democracy and Electoral Assistance). Voter Turnout Database. https://www.idea.int/data-tools/data/voter-turnout [2017-11-20].

16. Yu, R. P. The Relationship Between Passive and Active Non-Political Social Media Use and Political Expression on Facebook and Twitter. Computers in Human Behavior, 2016, Vol. 58, p. 413-420.

17. Kuzmickaitè, P. Pilietiškumo labirintai: kaip lietuviai reiškia savo valią? 2017. http://kaunozinios.lt/titulinis/pilietiskumo-labirintai-kaip-lietuviai-reiskia-savovalia_101123.html [2017-11-22].

18. Ohlin, J., Heller, A., Byrne, S., Keevy, N. How Young People Participate in Civic Activities Using Internet and Mobile Technologies. Report to the National Youth Affairs Research Scheme, 2010. https://docs.education.gov.au/system/files/doc/other/how_young_people_participate in civic activities_using internet_and_mobile technologies.pdf [2017-12-09].

19. Perugorría, I., Tejerina, B. Politics of the Encounter: Cognition, Emotions, and Networks in the Spanish 15M. Current Sociology, 2013, Vol. 61, No. 4, p. 424-442.

20. Putnam, R. D. Bowling Alone: The Collapse and Revival of American Community. New York: Simon \& Schuster, 2000.

21. Saxton, G. D., Wang, L. The Social Network Effect: The Determinants of Giving Through Social Media. Nonprofit and Voluntary Sector Quarterly, 2014, Vol. 43, No. 5, p. 850-868.

22. Smith, A. Civic Engagement in the Digital Age. Pew Research Center, 2013. http://pewinternet.org/Reports/2013/Civic-Engagement.aspx [2017-11-15].

23. Valenzuela, S., Arriagada, A., Scherman, A. The Social Media Basis of Youth Protest Behavior: The Case of Chile. Journal of Communication, 2012, Vol. 62, p. 299-314.

24. Wolfsfeld, G., Segev, E., Sheafer, T. Social Media and the Arab Spring: Politics Comes 
First. The International Journal of Press/Politics, 2013, Vol. 8, No. 2, p. 115-137.

25. Zaheer, L. Use of Social Media and Political Participation among University Students, 2016.

https://pdfs.semanticscholar.org/48b6/ee525291387a4a237c36b15ed524f00cf080.pdf [2017-11-15].

26. Zhang, X., Lin, W.-Y. Political Participation in an Unlikely Place: How Individuals Engage in Politics through Social Networking Sites in China. International Journal of Communication, 2014, Vol. 8, p. 21-42.

27. Zhang, X., Lin, W-Y. Stoking the Fires of Participation: Extending the Gamson Hypothesis on Social Media Use and Elite-challenging Political Engagement. Computers in Human Behavior, 2018, Vol. 79, p. 217-226

Jurgita Jurkevičienè, Eglè Butkevičienè

\section{Pilietinis dalyvavimas ir ịsitraukimas ị elektroninius socialinius tinklus: tendencijos Lietuvoje}

Anotacija

Pastaraisiais metais suintensyvejo diskusijos apie pilietinio aktyvumo skatinimą. Elektroniniai socialiniai tinklai ir kitos skaitmeninès platformos, siūlančios neregètas galimybes ívairioms veikloms, taip pat ir pilietiniam aktyvumui, pradètos akcentuoti kaip veiksnys, palengvinantis piliečių dalyvavimą. Šiame straipsnyje yra tikrinama hipotezè, teigianti, kad žmonès, kurie aktyviau dalyvauja elektroniniuose socialiniuose tinkluose, yra labiau linkę dalyvauti ir pilietinèse veiklose. Rezultatai rodo, kad dalyvavimo elektroniniuose socialiniuose tinkluose ir pilietinèse veiklose santykis iš esmès yra teigiamas. Konkrečiau nustatyta, kad specifinès tinklinès veiklos, tokios kaip „temų diskusijoms siūlymas“, „prisidejjimas prie organizuotų renginių“ ar „turinio viešinimas“, daro didesnę ịtaką pilietiniam aktyvumui už kitas veiklas.

Jurgita Jurkevičiene - Doctor of Social Sciences, is a Lector at the Faculty of Social Sciences, Arts and Humanities, Kaunas University of Technology.

E-mail.: jurgita.jurkeviciene@ktu.lt.

Egle Butkevičiene - Doctor of Social Sciences, is a Professor at the Faculty of Social Sciences, Arts and Humanities, Kaunas University of Technology.

E-mail.: egle.butkeviciene@ktu.lt.

Jurgita Jurkevičiené - Kauno technologijos universiteto, Socialinių humanitarinių mokslų ir menų fakulteto lektorè, socialinių mokslų daktarè.

E.paštas: jurgita.jurkeviciene@ktu.lt.

Eglè Butkevičienè - Kauno technologijos universiteto, Socialinių, humanitarinių mokslų ir menų fakulteto profesoré, socialinių mokslų daktarè.

E.paštas: egle.butkeviciene@ktu.lt. 
Straipsnis ịteiktas redakcijai 2017 m. gruodžio mèn.; recenzuotas; parengtas spaudai 2018 $\mathrm{m}$. vasario mèn. 